\title{
Les sites fortifiés protohistoriques de hauteur en Basse-Normandie
}

Pierre Giraud et Fabien Delrieu

\section{(2) OpenEdition \\ Journals}

Édition électronique

URL : http://journals.openedition.org/adlfi/7357

ISSN : 2114-0502

Éditeur

Ministère de la culture

Référence électronique

Pierre Giraud et Fabien Delrieu, "Les sites fortifiés protohistoriques de hauteur en Basse-Normandie », ADLFI. Archéologie de la France - Informations [En ligne], Basse-Normandie, mis en ligne le 01 mars 2007, consulté le 03 mai 2019. URL : http://journals.openedition.org/adlfi/7357

Ce document a été généré automatiquement le 3 mai 2019.

(c) Ministère de la Culture et de la Communication, CNRS 


\title{
Les sites fortifiés protohistoriques de hauteur en Basse-Normandie
}

\author{
Pierre Giraud et Fabien Delrieu
}

Date de l'opération : 2007 (PC)

Contrairement aux autres régions du nord de la France, la Basse-Normandie n'a jamais connu d'intérêt particulier pour les sites fortifiés protohistoriques. Même au plus fort de l'engouement suscité par les découvertes des sites de la guerre des Gaules à la fin du XIX e s. et au début $\mathrm{du} X X{ }^{\mathrm{e}} \mathrm{s}$., rares sont les archéologues locaux qui se sont véritablement investis dans l'étude de ces sites. Devant la multiplication des opérations récentes sur ce type de site (fouilles programmées de Saint-Pierre-des-Ifs - Saint-Désir «Le Castellier » (Calvados) par Pierre Giraud, Merri «Le Camp de Bierre » (Orne) par Fabien Delrieu et Banville «La Burette » (Calvados) par Gwenolé Kerdivel, diagnostic à Exmes « Le Bourg » (Orne) par Cyril Marcigny), il est apparu logique et nécessaire de structurer la réflexion à l'échelle régionale dans le cadre d'un projet collectif de recherche.

Cette première année de recherche a été particulièrement active, de nombreux sites ont pu être documentés que ce soit par de simples visites de repérage, par des relevés ou par des opérations de sondages et de fouilles. Le corpus établi en 2006 a été affiné et complété qualitativement. Plusieurs sites vérifiés ont également été retirés de la base de données suite à des vérifications de terrain, du fait de l'absence de structure défensive observable.

D'un point de vue scientifique, les opérations de fouilles et de sondages ont permis de renouveler la problématique sur les sites de hauteur protohistoriques aussi bien au niveau de leur fonction, de leur morphologie que de leur attribution chronologique.

Les sondages conduits à Igé «Le Crochemélier » (Orne) ont ainsi permis de confirmer la chronologie du site. Suite aux découvertes du docteur Jousset en 1866, il avait été possible d'attribuer ce petit éperon barré aux phases moyenne et récente du Bronze final. L'opération de 2007 a affiné cette attribution chronologique en la recentrant sur le Bronze final $3 b$. Des structures domestiques (bâtiments sur poteau ou sur tranchée de fondation, fosses, etc.) ont également été mises au jour pour cette phase chronologique. 
La coupe du rempart $n^{\circ} 2$ de Merri «Le Camp de Bierre» (Orne) a permis de documenter la structure de ce système défensif. Un rempart à masse argileuse et à poutrage interne était ainsi associé à une palissade sommitale implantée dans une tranchée. Ce barrage était précédé d'un fossé qui a été condamné à la fin du second âge du Fer. La chronologie même de ce système défensif devrait pouvoir être établie avec des datations ${ }^{14} \mathrm{C}$ sur les poutrages calcinés du rempart et sur les pieux de la palissade. Ces données viennent compléter les résultats des fouilles conduites en 2005 et 2006 qui avaient vu la mise en évidence de deux phases d'occupation distinctes centrées sur le Bronze final et la fin du premier âge du Fer.

L'opération conduite récemment (mois de novembre) sur le cap de Carteret dans la Manche a mis en évidence deux occupations distinctes (Néolithique Moyen et Bronze ancien) qui prennent place à l'extrémité de ce promontoire de schiste.

L'éperon barré de Vauville " La Lande à Carnet » (Manche) a pu être étudié à la suite d'un sondage mené sur le système défensif. Cette opération a permis de documenter le rempart parementé et le comblement du fossé. Il semble que l'abandon du site ait suivi de peu sa construction. Faute de mobilier datant, l'attribution chronologique de cette fortification reste à établir.

L'éperon du «Mont Cavalier» à Commes (Calvados) n'était connu que par son impressionnant rempart de barrage et la découverte de mobilier gallo-romain. L'opération de sondages réalisée dans le cadre de ce PCR a permis de reconnaître un fossé à l'avant de ce rempart et surtout une enceinte de contour. Une chaussée de galet de belle facture, mise au jour dans trois tranchées, longe ce système défensif. Les traces d'une occupation précoce du site (Néolithique ?) ont été repérées. Dans la partie occidentale de l'éperon, un lot important de mobilier céramique de la fin du premier âge du Fer témoigne d'une installation à cette période. L'enceinte, la chaussée et au moins une phase du rempart de barrage ont pu être attribuées à La Tène finale.

La campagne de fouille sur l'oppidum du Castellier à Saint-Désir (Calvados) a révélé un quartier de l'agglomération compartimenté par un petit réseau de fossés et de palissades. Plusieurs phases ont pu être mises en évidence dont une première consacrée au stockage de céréales et d'autres à des activités artisanales (forge et peut-être ateliers de potier). La densité de vestiges confirme le caractère préurbain du site, jusqu'alors connu uniquement par son enceinte de contour.

Ces différentes occupations sont venues compléter les données chronologiques identifiées lors du travail préparatoire. Les grandes phases d'occupation des sites de hauteur alors mises en évidence ont été confirmées par ces opérations : Néolithique Moyen (Cap de Carteret, Commes ?), Bronze final (Merri, Igé, Vauville ?), Hallstatt D (Commes, Merri) et La Tène finale (Commes et Merri). Sur ce point et pour cette première année de recherche, il semble que l'objectif initial de documenter les attributions chronologiques de plusieurs de ces sites ait été atteint.

DELRIEU Fabien et GIRAUD Pierre 
INDEX

operation Projet collectif de recherche (PCR)

Index géographique : Basse-Normandie, Orne (61), Igé (61207)

Thèmes : architecture domestique, artisanat, atelier de potier, céréale, chronologie, éperon

barré, fondation de bâtiment, forge, fortification, palissade, quartier, rempart, site de hauteur, stockage

Index chronologique : âge du Bronze, âge du Fer, Néolithique moyen, Protohistoire

\section{AUTEURS}

PIERRE GIRAUD

SDA

FABIEN DELRIEU

SRA 